\title{
"DEAR MISS ELLA": GEORGE L. CHASE'S WHITMAN-INSPIRED LOVE LETTERS
}

\author{
JON MiLLER
}

ON November 1, 1871, Walt Whitman inscribed a copy of his fifth edition of Leaves of Grass to George L. Chase in Washington, D.C. Letters recently discovered by Kendall Reed suggest that Chase deserves the attention of readers interested in the early reception of Whitman's poetry. Because twentieth-century scholars often described Whitman as a poet who offended the American clergy, some readers may be surprised to learn that Chase was an Episcopal minister and missionary who defended Whitman from charges of immorality, irreligion, and other "awful things." The letters reproduced below demonstrate how fully Chase absorbed Whitman into his life and thought; they are courtship letters to his future wife, and in them Chase employs Whitman as a guide to philosophy, ethics, and, finally, love.

It appears that Chase and Whitman met repeatedly for earnest, intellectual discussion. In his letter to Stephen J.W. Tabor (reproduced on the back cover), Whitman writes in October 1871 that he likes Chase "much" and that he has "known him many years."1 In the letters reproduced here, Chase recalls "private confessions" that Whitman made to him in 1862 . He also describes his 1871 visit as an intimate experience: "I will say that Walt gave me an 'inside view' of his ideas about himself," he writes, "telling me that he had rarely shown as much of his heart to any person." There is evidence of later meetings, too. Chase's correspondence describes frequent, cross-country travel, so there is reason to believe he would have had regular opportunities to visit Whitman on the east coast. In his letter to Ellen M. O'Connor, dated May 6, 1874, Whitman writes of "nothing new or different" in the same breath that he mentions he has "had a good long call from a friend from Minnesota." 2 This old friend could well have been Chase. In his 1877 daybook, Whitman stored a loose slip of paper noting Chase's Faribault, Minnesota, address. ${ }^{3}$ The address is not in Whitman's hand, and it is not accompanied by the date, salutation, or signature one would expect to find on a piece of written correspondence. This suggests that the note is a spontaneous written reminder, i.e., that someone, probably 
Chase, visited Whitman and urged him to write to that address. Finally, the last letter reproduced below suggests that Chase's wife had reason to believe that Walt Whitman would care to be notified of his death.

Not much is known of Chase's life. In 1860, he was working as an artist in Buffalo, New York. He was ordained in 1864 by Bishop de Lancey of the diocese of western New York. In his autobiography, the Rev. Henry Benjamin Whipple writes that Chase left New York "an invalid" who sought better health in the pure air of Minnesota. ${ }^{4} \mathrm{He}$ praises Chase as "one of the gentlest and wisest men" he had "ever known," an "artist, a scholar, a man of affairs" with "a passionate love for men who sin

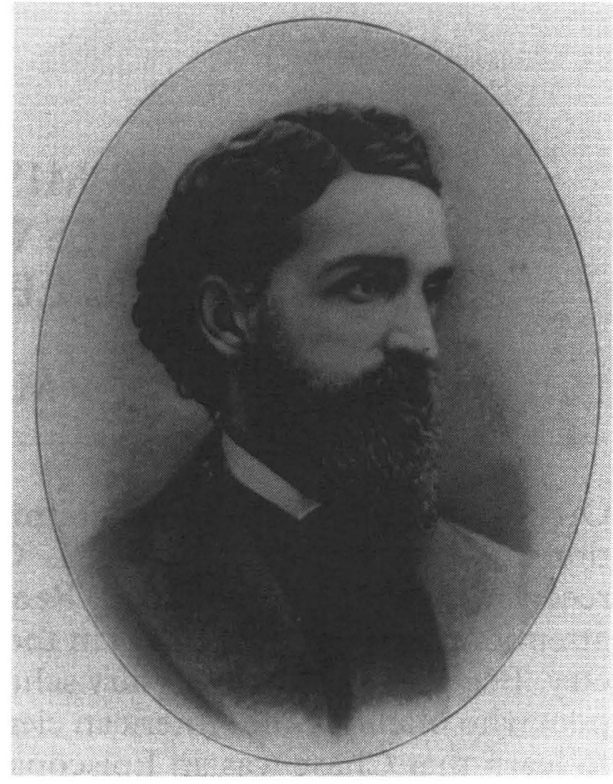

Rev. George L. Chase. From Fifty Years of Church Work in the Diocese of Minnesota, 18571907 (1909). and suffer." ${ }^{5}$ Elsewhere Whipple elaborates, describing Chase as the kind of humble literary democrat Whitman so often celebrated: "He was intensely human," he writes; "He was at home in the cottage and in the marble house, in the lumberman's camp and academic halls."

Chase had a distinguished career of church service in Minnesota before his death in 1883. He served in St. Cloud from 1866 to 1869, in St. Anthony from 1870 to 1873 , and he was Warden and Professor of Homiletics and Liturgies at Seabury Divinity School in Faribault from 1874 to 1883 . The move to Minnesota may have been suggested by family members: Chase was related to Philander Chase, the bishop of Ohio and Illinois, and Philander Chase's devoted son-in-law, Jacob Chamberlain, established the St. Cloud parish that George L. Chase would join ten years later. ${ }^{7}$ From 1858 to 1859 , St. Cloud was also the responsibility of Rev. Dudley Chase-another relative, perhaps (Tanner, 198).

The Minnesota missions were originally conceived in the 1840 s to minister to Chippewa Indians. More than twenty years later, however, Chase would have also served small, local congregations that were, in all probability, predominantly female and constituted mostly of recent emigrants. Church historian George Tanner notes that 1856 saw the beginning of a "large" emigration to Minnesota by way of the Mississippi. "For months," he writes, "there were at least three boats daily 
ascending the Mississippi loaded to the utmost extent with enterprising emigrants" (191). Still, the missionaries served a scattered and impoverished population that was unable (even if willing) to provide financial support. Consequently, the missions depended upon the donations received through the daily mail. In other words, Chase's abilities as a letter-writer were not unusual among mid-nineteenth-century Minnesota missionaries. As Tanner wrote of Rev. J. Lloyd Breck, a pioneer of the Minnesota missions, "Mr. Breck had the rare art of interesting people by his charming and picturesque letters, and had gradually drawn around him a large circle of admiring and enthusiastic friends" (39). Breck founded the school in Faribault where Chase taught for nine of the last ten years of his life.

In 1871, when Chase met Whitman and received the inscribed copy of Leaves (now in the Kendall Reed collection), Whitman was probably entertaining his philosophical friends with monologues like those that went into Democratic Vistas. Published in 1871, Democratic Vistas is comprised of a series of oratorical essays written between 1867 and 1870 . This prose suggests what Chase-from the wilderness state of Minnesota-might have offered Whitman as a subject for conversation and study. For example, Democratic Vistas portrays "the States . . . along the Ohio, Missouri and Mississippi rivers, and west and north of them" as a land of "solid personality" and "the deep quality of all-accepting fusion," as a land developing the "main social, political, spine-character of the States" in a people that "compact and settle the traits of America." Chase also may have represented the "sane and pervading," "all penetrating religiousness" that would justify Democracy were it "copiously" produced in the "perfect characters" of the future citizens of the United States (PW 2:392-393, 398).

After Chase left Washington, he apparently traveled south with his friend, Al Wheeler, and met Al's cousin, Ella Wheeler, at her home in Florida. Chase evidently spoke quite a bit about Whitman, and his conversation prompted Ella to express an interest in reading Whitman for the first time. As Minnesota thawed the following spring, Chase remembered Ella Wheeler and her interest in Whitman. Over the next six months, he worked to convert her interest in Walt Whitman into an interest in George L. Chase. In the following letters, Chase courts Ella Wheeler through literary discussion and poetic compliments.

These letters provide a new view of Whitman readers in the early 1870s. At the start, Chase describes the Whitman circle as almost exclusively male. He writes that "Ladies . . rarely 'take to' Walt Whitman." He finds hope for Whitman's popularity among women, however, in Anne Gilchrist's glowing review-he sent it to Wheeler, twice-and in Wheeler's growing interest in the poet. Furthermore, although Chase is quoting Whitman to win a wife, he appears to be completely unpersuaded by (or unaware of) criticism of Whitman's poetry as excessively or dan- 
gerously sexual. Chase was not one to forbid the reading of Whitman as, for example, Walter Stetson forbade his fiancé, Charlotte Perkins Gilman. As Joann Krieg has recently described, Stetson debated this prohibition in his diary, recording his original impulse to shield Gilman from a book that "stands in the market places and cries up the odor of its perspiration, the action of its phallus, the hairiness of sweating breasts." Stetson wanted their love to be more "holy" and "hidden" (Krieg, 253). Like Stetson's diary, the Chase letters also give us a rare insight into contemporary male reactions to Whitman's sexual imagery. Chase hints that Whitman's work has flaws, but there is no indication that he considers Whitman's sexuality a cause for concern. When Ella suggests they will meet again "as admirers of Whitman," Chase praises her "Christian faith" and proposes that "they join hands and be friends." They married not long after their next visit.

Finally, the Chase letters to Ella Wheeler also construct a strikingly idiosyncratic literary history in which to contextualize Whitman's writings. Chase quotes a number of classics that have been studied alongside Whitman's poetry, to be sure, but he also puts Whitman on the same bookshelf as Florence Nightingale, Henry Ward Beecher, F.W. Farrar, Elizabeth Stuart Phelps, Edward Robert Bulwer-Lytton, Edouard Laboulaye, Henry Taylor, F.W. Robertson, Goldwin Smith, and George Macdonald, Chase's favorite novelist. Chase indulges a taste for the romantic, the sentimental, and the mystical, but he also demonstrates a large appetite for Whitman. The quality and consistency of his literary criticism suggests that his choice of authors was studied, and not without merit.

The University of Akron

\section{NOTES}

I would like to thank Kendall Reed for his generosity in loaning me, for an extended period of time, the Chase letters and his notes on Chase, which included some biographical research undertaken by Janet Jurist.

1 Walt Whitman to John Tabor, October 31, 1871, in "The Correspondence of Walt Whitman: A Third Supplement with Addenda to the Calendar of Letters Written to Whitman," ed. Ted Genoways, Walt Whitman Quarterly Review 18 (Summer/ Fall 2000), 15-16.

2 Whitman, The Correspondence, The Collected Writings of Walt Whitman, ed. Edwin Haviland Miller (New York: New York University Press, 1961), 3:297.

3 Since Chase did not move to Faribault until 1874, the Faribault address is evidence of a later encounter with Chase or his representative; see Whitman, Daybooks and Notebooks, The Collected Writings of Walt Whitman, ed. William White (New York: New York University Press, 1978), 1:61 (hereafter abbreviated $D B N$ ). Chase is also listed in the homemade address book Whitman used from 1866 to 1877 . Here Chase 
receives mail at Minneapolis, suggesting Whitman may have recorded this address in 1871, when Chase was at St. Anthony (now a historic district in Minneapolis); see Whitman, Notebooks and Unpublished Prose Manuscripts, ed. Edward F. Grier (New York: New York University Press, 1984), 2:828.

4 Whitman, who regarded the West as a "Land of pure air!" and good health ( $D B N$ 3:631), would have understood Chase's decision to go to Minnesota to convalesce.

5 Henry Benjamin Whipple, Lights and Shadows of a Long Episcopate (New York: Macmillan, 1899), 244.

6 Whipple, quoted in George Clinton Tanner, Fifty Years of Church Work in the Diocese of Minnesota, 1857-1907 (St. Paul, Minnesota: The Committee of Publication, 1909), 356.

7 Tanner, 356, 186. Chase was also related, distantly, to Salmon P. Chase, the Secretary of the Treasury who rejected Whitman's application for a government office in 1863. His 1871 visit to Washington, D.C., may have been to the home of chief justice Chase.

8 Whitman, Prose Works 1892, ed. Floyd Stovall (New York: New York University Press, 1964), 2:385.

9 Joann Krieg, "Grace Ellery Channing and the Whitman Calendar," Walt Whitman Quarterly Review 12 (Spring 1995), 253-254.

\section{CHASE'S LETTERS}

To Ella Schley Wheeler

St Anthony, May 20th 1872

Dear Miss Wheeler

A recent letter from your cousin, and my dear friend, "Al", ${ }^{1}$ recalls (what I had not forgotten) my visit at your home last Fall and, among other incidents of it, your wish for a copy of "The Hymn" in Walt Whitman's "Singer in the Prison."

I believe the shortness of my stay prevented a copy being made at the time, and soon after my return to Minnesota, I made the copy which I now inclose, and put it into an envelope and directed it to you, but for some reason omitted to mail it.

Thinking as highly of Whitman as I do, as a poet and as a friend, I always hail with peculiar sympathy an appreciation of his genius in another, especially in a lady, from its rarity. You will of course understand me to mean not that ladies do not commonly like poetry, but that they rarely "take to" Walt Whitman. Walt himself gave me (at Washington in October last) the May (1870) No of the "Radical", containing "A Woman's estimate of Walt Whitman" being letters to $W . M$. Rossetti of London and pronounced by him "the most eloquent appreciation of Whitman yet put into writing." If your interest in the matter (on which I will not presume too far) should induce in you any curiosity to see the letters I will mail the magazine to you with much pleasure. 
Permit me to take one liberty further to send you a prose pamphlet by the same eccentric "Kosmos" (as he calls himself) entitled "Democratic Vistas," which I received from his own hands. I have another copy, therefore please retain this, if you will.

I am gratified to learn that your cousin is so contented and so well-employed as I infer that he is, at New Haven. Am I not correct in my inference?

I remember very pleasantly my visit at Florida, the beauty of its surroundings and the generous hospitality with which your cousin's friend was welcomed.

Please present my kindest regards to your father, mother, and sister, and believe me, with much respect,

Yours very sincerely

Geo. L. Chase

[Accompanying this letter is Chase's careful transcription of "The Hymn From 'The Singer in the Prison' by Walt Whitman" as it appeared on p. 95 of the Passage to India (Washington, D.C.: 1872) supplement to the fifth edition of Leaves of Grass.]

To Ella Schley Wheeler

St. Anthony, Min. June 9th, 1872

Dear Miss Wheeler,

I have your favor of the 26th ult and am very much gratified (and somewhat relieved) to find that I did not overestimate your interest in "Walt" (who seems to like being called by his "nigh name"). I have never known any lady but yourself to be at all acquainted with our poet. I have a lady-friend in St. Paul, a gifted and highly cultivated woman, the author of many published poems of no mean degree of merit, with whom I was talking about him not long ago. She had read nothing of his. Partly to awaken her interest and partly to note her impressions, sure to be valuable, (a recent London essayist says that the best criticism is simply a record of the impressions produced upon the best minds) I lent her the No of "The Radical" which I now take sincere pleasure in mailing to you, having just rec'd it again. She is so much delighted with the "Letters" that she thinks they might well have been written by Mrs. Browning. ${ }^{2}$ As my friend is the acme of all that is noblest and purest in womanhood and motherhood, I feel strengthened by her favorable estimate of the criticisms. I have shown the article to no one else and have not yet ventured to offer my presentation-copy of Walt even to her.

The English lady has well performed the more gracious part of the critic's office. She has understood him with profound sympathy and interpreted him with rare discrimination. He could not expound his tenet so well himself. Once when I asked him the meaning of a certain passage he rejoined -"What does it seem to you to mean? I mean that."

But I must be allowed to criticize the fair critic, very mildly, for I admire her greatly. I think she accepts Walt too wholly and with too absolute a trust. She acts too implicitly on his "great law of reception, neither preference nor denial. ${ }^{3}$ He himself is sometimes, tho' rarely, inconsistent with it, as when he 
speaks contemptuously (and justly) of "foofoos" (!). ${ }^{4}$ I believe we ought "to refuse the evil and to choose the good" as he himself intends to in rejecting errors and narrownesses of the past. ${ }^{5}$ Her likening of his poems to a forest, while others are like a palace or a cathedral is suggestive but must not be taken too literally.

Aristotle says "Poets must be either frenzied or skillful." I suppose the one makes "forest"-poems - the other "palace"-poems. No one can dispute the superiority of the former. But tho' Art cannot rival Nature, she may make nature surpass herself. The greatest poets should be - and are - both frenzied and skillful-as Homer, Dante, Shakespeare. Hamlet's advice to the players will apply to poets "Use all gently: for in the very torrent, tempest, and (as I may say) whirlwind of your passion you must acquire and beget a temperance, that may give it smoothness." While on the one hand over-elaboration destroys life and produces "cold and wire-drawn odes" (as Mrs. Browning says); on the other hand, tumultuous feelings, expressed without the restraint which Hamlet indicates, result in strained and incoherent utterances, from which Walt's pages are not free. He says truly "I sound my barbaric yawp over the roofs of the world." 9

Wm Blake was a genius and gave the world some fine pictures \& poems, but most of his works in both spheres of art, are a magnificent jumble.

The poet must be an artist—or as the word itself means a maker. His office is to give perfect expression to truth and to man's aspirations for truth.

Disagreeing with the English lady, I do not think poetry will own this man as equal with her highest completest manifestors (nor take the alternative she proposes).

I cannot undertake to put into this letter all that I could say on his behalf. The "heart-sympathy" which you perceive in him is one of his strongest points.

"Agonies are one of my changes of garments.

"I do not ask the wounded person how he feels-I myself become the wounded person."-10

In an age when free-thinking tends to a disbelief in a hereafter-when so many good men fear-

"That each, who seems a separate soul,

Shall move his rounds, and fusing all

The skirts of self again, shall fall

Remerging in the general whole" - ${ }^{11}$

-it is reassuring to find a strong, even audacious thinker who can say

"Pleasantly and well-suited I walk:

Whither I walk I cannot define but I know that it is good.

The Past and the Present indicate that it is good. The whole Universe indicates that it is good." 12

I love to find fearless confidence in certain convictions of truth coupled with deep humility both as to the actual and the possible range of our knowledge. I 
shall never forget the calm dignity with which Walt read to me last fall the following passage from his "Elemental Drifts"-

"O baffled, balk'd, bent to the very earth,

Oppressed with myself that I have dared to open my mouth,

Aware now that, amid all the blab whose echoes recoil upon me, I have not once had the least idea who or what I am,

But that before all my insolent poems the real ME stands yet untouched, untold, altogether unreach'd,

Withdrawn far, mocking me with mock-congratulatory signs and bows,

With peals of distant ironical laughter at every word I have written,

Pointing in silence to these songs, and then to the sand beneath.

Now I perceive that I have not understood anything."13

As I cannot get to the end of this subject, I will leave it here for the present, only adding a request that you will favor me with your impression of the "Letters to W. M. Rossetti."

I shall be glad to call upon your friend should she come to Minnesota. St Paul is but 9 miles from here. I shall hope to have the address soon. I know indeed that in a far country to come from the same state is a strong bond.

I shall set it down as a pleasure to be counted on, to accept your kind invitation to visit Florida again-sometimes I can fancy how it may look in the tender green of early June. The country here is beautiful now-tho' of course wilder than with you.

I had occasion to go to Willmar a new "city" on the St Paul and Pacific Road, west of here, last week to lay the corner-stone of a new church and during a long drive thro' the woods and along the shores of lakes I luxuriated to the fall in "The leaves and flowers of the commonest weeds, the moist, fresh stillness of the woods." ${ }^{14}$ I gathered an armful of wild flowers, Daisies white \& blue, Oxalis, Jack in the Pulpit, Solomon's Seal, Craw's foot, Puccoon, and many others.

I was so reminded of you by being the guest of a family named Burtis, Mrs. B. being a Dolson from Dolsontown, near Middletown Orange Co. She has been in Florida and knew of your family well. It was a pleasant discovery to make so far away. Her home, tho' abounding in books, pictures, \&c. is in one of the extreme border towns. As an indication of this I may mention that the train which I took on my return, when but a short distance from Willmar started up a deer, which ran near the track ahead of the locomotive for about 3 miles till finding that steam was gaining in the unequal race, he faced about, gained a new conception of the situation and struck out across the prairie at a right angle. A curious incident occurred not long ago. A photographer was taking views of wild scenery. Just as his instrument was in readiness, he espied a beautiful fawn within range. Adjusting his camera he secured a negative of the wild creature from life "on its native heath," 15 a feat which may never have been achieved before. I beg leave to inclose a print of it.

I am gratified to know that you are practically interested in Western missions. But my letter has reached such a length that I must break it short off somewhat abruptly. I have just heard from "Al" and mean to write to him today. Hoping for the favor of an early reply, I beg leave to call myself, tho' as you say "a stranger," 
Respectfully \& sincerely

Your friend

My kindest regards to your family.

Geo. L. Chase

To Ella Schley Wheeler

St. Anthony July 4th 1872

Dear Miss Ella

I will not stop to tell you why but will merely mention the fact that the week which has elapsed since I received your last has been the busiest of a busy half-year, so that I have had to lay your letter aside.

I mailed "The Radical" ( $\&$ a pamphlet with it) at the same time with my letter to you. I am forced to conclude that we have lost it. I shall make an effort to obtain another copy, but may not succeed. I really want you to see the article. Thank you for your kind intentions about the parody.

You ask if Walt is an egotist - as others have charged and as he asserts himself to be. Perhaps I should answer with the circumspection of Martin Van Buren about whom a bet was made that he would not give a direct answer to the simplest question. This was the result.

Qu. Mr Van Buren, does not the sun rise in the East?

An. Sir, the words "East" and "West" are conventional terms.

I will say that Walt gave me an "inside view" of his.ideas about himself last Fall telling me that he had rarely shown as much of his heart to any person. $\mathrm{He}$ believes that he has taken a step beyond all other writers in recognizing the full value of a man, as such, in the scheme of the Universe, accepting and glorifying him just as he is "with all his imperfections on his head." 16

This being his conviction of his own work, he fearlessly claims it. "Who thinks the simplest thoughts? For I will surround those thoughts. And who has made hymns fit for the earth? For I am mad with devouring extasy $\mathrm{f}$ to make joyous poems hymns for the whole earth!" 17

This is certainly a kind of egotism. Elsewhere he says

"I invite defiance and to make myself superseded.

All I have done, I would cheerfully give to the trod under foot, if it might only be the soil of superior poems." 18

Poets have been distinguished as Universal and Egotistic - the former sympathizing with all men-the latter making all to sympathize with them. Shakespeare is the type of the former-his individuality kept out of sight "vox, et praeterea nihil." ${ }^{19}$ Milton of the latter, showing himself, his culture, his leanings, his prejudices, in all he has written.

Walt seems to me to combine these characteristics remarkably. I think he has more of the quality of universal sympathy, than of self-obtruding egotism. 
The Ego whom he means is often man - he takes himself as a representative homo, and speaks for the race. And he appeals to all to think as much of themselves as he does of himself and them. I value chiefly not his ideas, his conclusions, his reasons, but his strong conviction

"Lo, Soul, see'st thou not, plain as the sun, The only real wealth of wealth in generosity, The only life of life in goodness?"20

It is something, it is a great thing, to see that, "plain as the sun"-or at least to feel unwavering confidence that these things are so!"

"Una and her Paupers"21 I have seen noticed repeatedly but have so far failed to procure it. I shall now do so, reinforced by your so earnest approval of the work. It does indeed fill one with awe and admiration to see a life so unselfishly consecrated, not merely to good works, but to menial services - as the servant of servants. We feel that the choice is wise and well and it strengthens our faith in that "hard saying"-_"He that loseth his life for my sake shall find it." 22

"Seekers after God"23 has been on the shelf allotted to my favorites, for several years-and long before, Marcus Aurelius had been "grappled to my soul with hooks of steel." 24

I am sure you will not misunderstand me if I tell you that there have been times of trial when "The Thoughts" of the Emperor have furnished just the antidote and tonic which I seemed to need.

Not long ago I was looking over the books of a lady in a little frontier town and discovered that Seneca's "Morals" was her constant companion.

And in another still more remote spot I found a lady who appeared to choose unaffectedly such "light reading" as Epicetus, "Faust", "Sartor Resartus" and "Wilhem Meister." Withal she was gentle and womanly, and a most watchful mother.

You allude to "Gates Ajar." 25 I wish you had given me your opinion of the book. I think it on the whole a praiseworthy and useful little contribution to the literature of the Future State. It was just enough above the unenlightened notions of the masses on the subject to meet (after a sort) a common want. I cannot wholly commend its audacity in ^the manner of^ treating such a subject. I do not like one to affect to be too much at home in that world which "eye hath not seen."

The authoress is said to be engaged to a Rev Mr Stimson, an excellent young clergyman of this city. Let me explain that Minneapolis ^pop. about $24,000^{\wedge}$ includes St Anthony which retains it's [sic] P.O. tho' it has lost it's [sic] separate identity as a city. Rev Mr S. lives on the other side of the River.

Before we leave the subject of authors, I am curious to know if you are fond of Robert Browning. I will not attempt to discuss him so near what should be the end of my letter. But I will say that he is one of my foremost literary friends.

I have just been reading "Lucile" 26 which I glanced at years ago and intended never to read; but a friend persuaded me into it and I am not sorry. Have you read it. 
And for sheer diversion I have had "Laboulage's Fairy Book"27 within reach for a few days. One of the stories-"Abdallah"-is exceedingly entertaining. But I must cut short what I am tempted to say of these works.

If you would tell me something definite of the nature of Miss Pierson's illness, I might be able to judge at what season she had better come to Minnesota-if at all. My duties here bring me into acquaintance with many seeking health more sedulously that Arthur's Knights sought the Holy Grail-in many cases as vainly - in many others successfully. I hope your friend may not be past cure. Is there no hope that you may yet yield to her persuasions. The companionship of a true friend will be better than medicine to her. I do think that some of our invalids find a purer air only to die of homesickness - a failing I am very lenient to.

The presence of so many persons in delicate health gives a perceptible coloring to Minnesota society - not the somber one you might expect, but rather of vivacity, gentleness \& refinement beyond what might be looked for in a border state. I do not wonder that visitors from Eastern cities are often so won by the fascinations of life in the North West as to prefer a residence here.

I have never been in Hudson, but if I ever go there which is not unprobable I shall hope to meet your friends the Misses M'Cartney.

I am glad to hear what you say of the contented tones of "Al's" letters. $\mathrm{He}$ has not been contented in any previous collegiate position.

I await with much interest and no small degree of anxiety the development of his plans for permanent work.

Let me ask if you have the "Painted Cup" or "Indian Pink" among your wild-flowers in Orange Co. I inclose a bit of it, which has been pressing (or being pressed) in a Quarto since Monday, when during a drive of 20 miles I gathered a large quantity of wild-flowers, conspicuous among which was the Tiger-Lily which abounds on our prairies, the Larkspur and the delicate purplish-blue harebell - and now, as I am so near the bottom of this page I shall but slightly aggravate my offence of expressing excess if I venture to give you one quotation from Robert Browning (you will see what put it into my head just now). It is a rather over-drawn portrait of Mildred, from "The Blot on the 'Scutcheon."

"There's a woman like a dew-drop, she's so purer than the purest;

And her noble heart's the noblest, Yes, and her sure love's the surest;

And her eyes are dark and humid, like the depth on depth of water,

Hid $i$ ' the harebell, and her tresses, sunnier than the wild grapes' cluster,

Gush in golden-tinted plenty down her neck's rose-misted marble:

And her voice's music, - call it the rill's murmur, the bird's warble." 28

I will ask you to punish the unpardonable length of my letter according to the "lex talionis." 29 
Be kind enough to remember me very cordially to your parents and sister. I think, Miss Ella, I may infer your permission to subscribe myself

Your sincere friend, Geo. L. Chase

Will you kindly let me know if "The Radical" has perchance come to light during this interval.

To Ella Schley Wheeler

St Anthony, Aug 18th 1872

\section{Dear Miss Ella}

My unfinished letter to you has grown so cold that I will not try to resuscitate it, but will take a fresh start. In explanation of my tardiness, let me say that the past month has been one of singular mortality among children in this community - nine funerals (eight being those of children) having occurred in my cure in that time. As almost every such case involves a great number of visits, the demands upon my time have been unusually frequent. The above fact may seem to detract from what I have said of the healthfulness of this climate. I do not think it a very favorable climate for children. This year however appears to be marked by a prevalence of fatal sickness among children all over the country. Unless you have been much with the sick and afflicted, you cannot readily imagine the drain upon the sympathies from long-continued contact with such cases. The result would perhaps be a morbid view of life as if the whole world were draped in black, except for "the law of compensation" as Emerson calls it. ${ }^{30}$ which tends to restore the equilibrium by a heightened sensibility to humor. Mr Lincoln once said in answer to the charge of being a "jester" that if it were not for the escape value of humor the war would have killed him long before. Yet this reaction will not (or at least should not) wholly efface the lesson of pathetic experiences.

As Taylor says so well in "Philip Van Artevelde" 11

"He that lacks time to mourn lacks time to mend.

Eternity mourns that.

Where sorrow's deemed intrusive and turned out

There wisdom will not enter, nor true joy,

Nor aught that dignifies humanity."

By the bye, is that work among your favorites? If not I would bespeak a place for it.

On the very day when I read your last letter, I obtained another copy of "A woman's estimate of Walt Whitman," after an exhaustive canvass among the subscribers to "The Radical" in this region. I see that the magazine has recently become defunct. I was about to apply to Walt himself, as a last resort, 
to help me out, if possible. For greater security I will detach the article from the rest of the number and inclose it in my letter. I am obliged to request its return but only at your perfect leisure.

When in College I saw some stories in an old volume of the "Democratic Review" signed "Walter Whitman" our veritable bard I doubt not; yet a very different character now from what he was then, I fancy. His extravagances are not those of youth.

You second your friend's question whether he is not a Pantheist. Do you wish the question answered from his works or from his private confessions. Perhaps a little of both. In the first place what is that awful thing, a Pantheist.

We are apt to define him negatively as one who does not believe in a personal God. But the positive view of what he does believe is probably fairer. Robertson (F.W.) say[s] "Pantheism is a tendency to see the godlike everywhere the personal God nowhere." ${ }^{32}$ And he remarks that Wordsworth was accused of Pantheism and also with equal justice of its opposite High Churchism ("the tendency to localize the personal Deity in certain places, times, and acts"). He cites the lines on "Revisiting Tintern Abbey"

And I have felt

A presence that disturbs me with the joy

Of elevated thoughts: a sense sublime

Of something far more deeply interfused,

Whose dwelling is the light of setting suns,

And the round ocean, and the living air,

And the blue sky, and in the mind of man:

A Motion and a Spirit, that impels

All thinking things, all objects of all thought,

And rolls through all things."

This R. calls "the very germ of Pantheism." Not so very deadly doctrine this. Compare such passages from Walt as this

"A vast similitude interlocks all,

All spheres, grown, ungrown, small, large, suns, moons, planets, comets, asteroids

All the substances of the same and all that is spiritual upon the same

$\mathrm{x} \times \mathrm{x} \times \mathrm{x}$

All lives and deaths - all of the past, present, future

This vast similitude spans them and always has spanned, and shall forever span them, and compactly hold them and enclose them." ${ }^{33}$

I think every great Poet has given expression to quasi-pantheistical sentiments. Mrs Browning says in Aurora Leigh (which I haven't at hand to ensure accuracy)

"If we could see $\mathrm{x} x$

The spiritual significance burn through

The outward semblance of material show

Henceforward we should paint the

globe with wings

And worship everything." \&c. ${ }^{34}$ 
To be sure Mrs B. and W. have seen and spoken the counter-truth of a personal God with a less uncertain sound that Whitman has, whose faith, which he has in full measure, is rather in the attributes \& laws of God than in his individual Being. Materialist he certainly is not. Witness-

"Thought of the Infinite- the All!

Be thou my God.

Thou-thou the Ideal Man!

Fair, able, beautiful, content, and loving,

Complete in Body, and dilate in Spirit,

Be thou my God.

O Death-(for Life has served its term;)

Opener and usher to the heavenly mansion!

Be thou my God." ${ }^{35}$

So far his works testify that he is in a certain sense a Pantheist, but much more!

I once had a talk with him on the subject. Among other things he said "I have accustomed myself to think of the laws of Nature as the only God, and yet there are many times and moods when it seems to me that all they say of a personal Providence is true-yes, it seems to me now as if it all were all so!"

That conversation was 10 years ago. I think he has no settled theology nor philosophy. He is content and more than content-ecstatic with strong perceptions and feelings, convinced that these "lay hold on eternal life."

It must be confessed, Miss Ella, that "the disaster" taught by the assertion of perceptions and feelings and that the formulating of them into "doctrines necessary to salvation" was an after-work. "He that is of the truth heareth my voice." 38

I need not renew the criticisms which I made on "A woman's estimate of Walt Whitman" on first mailing you the magazine.

I once deprecated to him the freedom of speech which had excluded him from the notice of many whom he might have helped.

He replied "Perhaps you are right-I think it very likely you are right."

The parody on him was very successful. While I don't like a parody on a particular poem which I may be specially fond of, I enjoy a racy imitation of the general style of an author. ${ }^{39}$

Prof. Goldwin Smith's critique on Lucille is very happy. ${ }^{40}$ Her turning a nun is quite in keeping, however, with the scenic picturesqueness and sentit sentimentalism with which the whole poem is surcharged. The "stage properties" introduced are too much a la Willis, whose "Love is at home in a parlor."

"His foot wing is the fan of a lady

His foot's an invisible thing.

And his arrows are tipped with silver,

And shot from a silver string." ${ }^{41}$

But the story has points of interest and Lucile has noble traits and I do not regret one reading. I doubt if I ever afford a second in this over-crowded world where "Art is long and time is fleeting." ${ }^{42}$ 
Are you a lover of George Macdonald? ${ }^{43} \mathrm{I} \mathrm{am}$. Not wholly blind to his errors, though. His "Annals of a Quiet Neighborhood" is a marvel of psychological dissection - and full of earnest promptings. Its continuation in "The Seaboard Parish" is a slight falling off. The sequel in "The Vicar's Daughter" I am just beginning in The Sunday Magazine. ${ }^{44} \mathrm{His}$ "Within and Without" interested yet disappointed me. In dramatic construction it is clumsy and there is a lack of verisimilitude in the incidents. I am afraid Macdonald is not a poet. $\mathrm{He}$ has the poet-soul \& insight I think, but I am led from this work to fear that he may not be a good artist in verse - at least not in the drama.

How different is the modern psychological story from the former love and murder, tricopherous (=hair-raising), narrative.

You make a remark in regard to the extent of my field of labor.

I have in fact a kind of double charge, comprising the rectorship of a parish in St Anthony and a missionary superintendency of what is called "the Northern Convocation" which includes about $1 / 3$ of the State (geographically much more than that). Of course I could not discharge this twofold trust without an assistant. It makes an enjoyable combination of duties. A missionary who is always itinerating feels that he is so to speak "scattering his fire" and there is a discouraging want of progressiveness in his work. It is therefore apt to become slipshod and spiritless. The definite, continuous, systematized work of a pastor is far preferable in that respect.

But on the other hand a Rector is in danger of settling down into the idea that he is a mere parish functionary-that when he has gone his rounds he has done enough - and of forgetting that he is "debtor unto all men". A missionfield with its undefined needs and unanticipated emergencies supplies a certain needful impulse in that direction. Of course many large parishes contain within themselves the elements of such a double work and relation-that of pastor \& that of missionary. It is hard for me to say which I like the best. I would not willingly give up either.

My mission-drives take me on some quite long journeys and show me some parts of the State not on the great thoroughfares of travel. Some years ago I drove from this place to Otter Sail Lake camping out at night-falling in with a party of Indians returning from the war-path with trophies-reaching a settlement of Mormons followers of the younger Joe Smith, on Lake Clitherhalland seeing a great deal that was to me "rich and strange." 45 I brought home a quantity of very hasty sketches of scenery \&c. and from one of my hurried pencillings I have made you a mere outline of a little lake not named on the map, about 10 miles west of Battle Lake. It is rather a characteristic Minnesota landscape-a small lake, with low banks and long points of land, and a foreground of rolling prairie. That is what you would see almost anywhere in "the land of the sky-tinted waters." 46

As I dislike to be responsible for unreliable rumors, let me say that I asked the lady who told me of Miss Phelps' engagement, whether she knew anything about it and learned that she did not.

I have deprived myself of the privilege of hearing from "Al" for a long time by failure to write to him. I hope to repair the neglect soon. I envy him his aquatic vacation. I should be an enthusiastic sharer in your pic-nics \&c to which you very kindly invite me-were not this just now the inexorable post of duty. I cannot tell when I may get away. 
Please remember me very heartily to all your family and to $\mathrm{Al}$, and believe me, Miss Ella,

Your very sincere friend, Geo. L. Chase

To Ella Schley Wheeler

Lockport, Oct 13 th 1872

\section{Dear Miss Ella}

Yours of the 30 th ult. forwarded to me from St Anthony, came a few days ago. I have to thank you-not as a piece of formal politeness-but very sincerely for several things in your letter. First for your delicate expression of unobtrusive sympathy. I have reflected many times since I wrote you about my two brothers, that it must seem very strange to you to receive such an autobiographical outpouring from a "stranger," as you have once or twice very properly called me. It is not always pleasant to be made the repository of gratuitous confidence and I feared that I might have been indelicately communicative. Indeed (like Shylock in reference to his perverse sentiment towards Antonio[D] I can give no reason nor I will not why I should have freely rehearsed to you experiences hitherto shared by almost none. I felt that you would understand me and so I yielded to the impulse to speak. Your kindness reassures me that if I erred, I am forgiven. I certainly would have you know (as I trust you do by intuition) that I do not blab of my most sacred hopes and longings to all the world nor "wear my heart upon my sleeve for daws to peck at." 47

You asked me in a previous letter whether - should we ever meet againit would be as admirers of Walt Whitman. He may have served to promote an acquaintance to which "Al" furnished the introduction but I feel, Miss Ella, that the course of our incidental correspondence has disclosed to us other common ground than that covered by "Leaves of Grass." May we not meet-not under the shelter of any poet's name- but as fellow climbers towards the First True, First Perfect and First Fair, to desire which above all else is the highest blessedness of this life- to attain which is Heaven. I do not here use the terminology of "religion" because it is so apt to degenerate into unreality and cantpartly too because I would include in one fellowship many who did not, or cannot, pronounce the shibboleths of orthodoxy but who yet are "seekers after God"48 - and who are, as I believe, so recognized by our Lord Himself as among them who shall come from the East and from the West $\mathrm{xx}$ and sit down in the Kingdom of God.

I dislike the cant of pseudo-liberalism even more than that of the "unco guid and rigidly righteous," 49 leaving all which aside, let me say that I have thought that I could see in you a Christian faith, well-founded and uncompromising, yet broad and tolerant and hospitable to every truth, though clothed in a garb no matter how "gentile"; and upon this interpretation of your inner self, I would esteem it a privilege to join hands and be friends with you, for our own sake and not another's. 
I thank you too for "These Summer Days." of strong true feeling. I have been reading them to my mother who admires them very much. That same dear mother has just placed on the table by my paper a flat dish filled with fresh flowers, chiefly white and pink balsams, and "pansies, that's for remembrance" (my favorite flower, I do think). ${ }^{51}$

Her flowers and grapes are very tempting but I think I shall leave them towards the last of this week for Boston-on the round of visits I spoke of, to which you have given me leave to add one which I shall be very glad to make, unless prevented by calls upon my time not now foreseen. I infer from your letter that your sister will be absent for some weeks. I suppose it will be near the last of the month before I can start from N.Y. on my return, when if that will chime in with your own plans, I shall hope to avail myself of your invitation. I mean to go to New Haven.

I have been writing these last few pp in the dusk. There is just enough light for me to ask leave to call myself, unconventionally and in reality,

Your friend

Geo. L. Chase

Kind remembrances to your father and mother

My address during next week will be

Care Hon H. F. French ${ }^{52}$

13 Studio Building

Boston

Mass

After that

Care Dr. P. P. Wells ${ }^{53}$

158 Clinton St

Brooklyn N.Y.

To Ella Schley Wheeler

N.H. Jan. 7, 1884.

My Dear Cousin El,

I have your line in regard to Walt W. If Will $F \cdot{ }^{54}$ has not already written to him, I will do so on my return f. N. Y. where I start in a few moments. ${ }^{55}$ Perhaps I had better write him anyhow.-Curiously enough I got out my Whitman "Literature" a few weeks ago.

Its very cold. I hope you will soon recover your tone, $\&$ be ready for your trip \& I remain, 
dear Cousin, with deep

Sympathies for you,

Your Cousin,

A.S.W.

\section{NOTES}

1 In an undated, handwritten note stored with the Chase letters, Florence Lee identifies "Al" as "Alfred or Albert Schley Wheeler," a "Professor at Cornell University." Florence Lee had an important role in the preservation of these letters. She acquired the Chase collection after the death of Rev. Mr. Chase's daughter, an artist who spent the last eighteen months of her life in Lee's home in Buffalo, New York. Florence Lee gave the Chase collection to another tenant, John Daniels. A great admirer of Walt Whitman, John Daniels wrote books and delivered lectures promoting American democracy and international harmony. He gave the collection to his son, Whitman Daniels, who was born in Florence Lee's home on July 20, 1910. Whitman Daniels sold the Chase collection to Kendall Reed.

2 Anne Gilchrist was not publicly revealed as the author of "A Woman's Estimate" until the publication of Whitman's As a Strong Bird on Pinions Free (1872).

3 Chase slightly misquotes Whitman, who writes of the "profound law of reception" in "Song of the Open Road," Leaves of Grass (Washington, D.C.: 1872), 178. Since it is most likely that Chase knew Leaves of Grass from the study of his inscribed fifth edition, I will cite his quotations to that edition and abbreviate it $L G$ (1872).

4 "Walt Whitman," $L G$ (1872), 52: "Washes and razors for foofoos-for me freckles and a bristling beard."

5 Isaiah $7: 15$.

6 Chase paraphrases a comment from part 17 of Aristotle's Poetics.

7 An essentially accurate quotation from Hamlet, III:ii.

8 Chase quotes the first book of Elizabeth Barrett Browning's Aurora Leigh (1856). Discussing the ardent, naïve poetry of youths who "Touch not, do not taste, / Nor handle," Browning cries out, "What make-believe, / With so much earnest! what effete results / From virile efforts! what cold wire-drawn odes / From such white heats!" See Browning, The Poetical Works of Elizabeth Barrett Browning (London: Smith, Elder, \& Co., 1897), as reprinted electronically in the English Poetry Database, an online resource first published in 1992 by Chadwyck-Healey Inc. (Alexandria, VA) and licensed to many research institutions. Other quotes taken from the electronic reprints available in the English Poetry Database or its companion resource, the American Poetry Database (first published 1996), will be cited as "as rpt. EPD" or "as rpt. APD."

9 "Walt Whitman," $L G$ (1872), 95.

10 "Walt Whitman," $L G$ (1872), 71.

11 Chase slightly misquotes the first stanza of part XLVII of Alfred Tennyson's "In Memoriam A.H.H." (1850). He has "shall" for "should," writes "soul" where Tennyson wrote "whole," and vice versa.

12 Here Chase jumbles a stanza from "To Think of Time," from page 59 of Passage to India, bound into the fifth edition of Leaves with separate pagination. Citations to Passage to India will be abbreviated Passage, LG (1872), and the separate pagination 
will be noted as "sep. pag." He has the third and fourth lines reversed, alters the punctuation slightly, and adds his own emphasis.

13 “Sea-Shore Memories," Passage, LG (1872), sep. pag. 79.

14 “A Poem of Joys," Passage, LG (1872), sep. pag. 44.

15 This may be an allusion to Matthew Arnold's "Haworth Churchyard" (1855), his meditation on the death of Charlotte Bronte and Harriet Martineau, or to the second part of James Drummond Burns's "Atlantis" (1858). In neither case would the quote be particularly appropriate.

16 Hamlet, I:v.

17 "Excelsior," Passage, LG (1872), sep. pag. 105. Whitman asked "who thinks the amplest thoughts?," not "who thinks the simplest thoughts?"

18 "So Long!," the concluding poem to 1860-1861 edition. Walt Whitman, Leaves of Grass (Boston: Thayer and Eldridge, Year 85 of the States, 1860-1861), 452.

19 A quotation from Plutarch: "[You are] a voice, and nothing more."

20 “Brother of All, with Generous Hand," Passage, LG (1872), sep. pag. 110.

21 Chase alludes to J. Jones, Una and Her Paupers: Memorials of Agnes Elizabeth fones, By Her Sister, intro. Florence Nightingale, first American edition, with an introductory preface by the Rev. Henry Ward Beecher (New York: G. Routledge and Sons, 1872).

\section{Matthew 10:39.}

23 The Rev. F.W. Farrar's Seekers After God (1868) was a book-length study extolling the Christian virtues of three heathens: Seneca, Epictetus, and Marcus Aurelius. Chase undoubtedly drew on this book as a superintendent of Episcopal missions to the Native Americans in northern Minnesota. "Let us admit with shame and sorrow," Farrar writes in the introduction, "that some among these heathens showed themselves to be nobler, loftier, holier, freer from vanity, freer from meanness, freer from special pleading, freer from falsehood, more spiritual, more reasonable, on some points even more enlightened, than many among ourselves" (Farrar, Seekers After God [London: Macmillan \& Co., 1881], xii).

24 Hamlet, I:iii.

25 Gates Ajar (1868) was perhaps the most popular work by the prolific Elizabeth Stuart Phelps (Ward) (1844-1911). Like Wheeler and Chase, Phelps was an enormous fan of Elizabeth Barrett Browning. She married a much younger journalist, Herbert Dickinson Ward, in 1888.

26 Published pseudonymously, Lucile (1860) was one of Edward Robert BulwerLytton's popular verse romances. George could have learned that this was one of Ella's favorite books from their mutual friend Al: the Kendall Reed collection contains a manuscript poem, "On returning 'Lucile,"” written in March 1871 for "Miss W." by "G.S.," perhaps an earlier suitor. Notes on the poem indicate that this manuscript is a copy made by Al Wheeler later that year. Ella preserved Al's copy of the poem with George's letters.

27 Chase has been reading Edouard Laboulaye, Laboulaye's Fairy Book: Fairy Tales of All Nations, trans. Mary L. Booth (New York: Harper \& Brothers, 1866). 
28 A mainly accurate quote from Robert Browning's "A Blot in the 'Scutcheon: A Tragedy" (1843). Robert Browning, The Poetical Works of Robert Browning (London: Smith, Elder \& Co., 1888-1894), as rpt. EPD.

29 Chase asks for a long letter as punishment for his long letter, i.e. a "punishment" of equal and direction retaliation, "an eye for eye, a tooth for a tooth."

30 Emerson describes the "law of compensation" in his 1841 first-series essay, "Compensation."

31 Chase quotes Henry Taylor's "Philip Van Artevelde" (1834), a British verse drama set in fourteenth-century Ghent about a pacifist political leader who demonstrates surprising ability and strength.

32 The Rev. F. W. Robertson was a highly regarded British theologian and literary critic. His lectures on poetry were well known in their day and have been reprinted many times since. Chase quotes "Wordsworth," a lecture delivered in February 1853. See Robertson's Lectures on the Influence of Poetry and Wordsworth (1906; rpt. Port Washington, N.Y.: Kennikat Press, 1970), 163.

\section{3 “Sea-Shore Memories," Passage, LG (1872), sep. pag. 85-86.}

34 The original quote runs thus: "If a man could feel, / Not one day, in the artist's ecstasy, / But every day, feast, fast, or working-day, / The spiritual significance burn through / The hieroglyphic of material shows, / Henceforward he would paint the globe with wings, / And reverence fish and fowl, the bull, the tree, / And even his very body as a man." Elizabeth Barrett Browning, "Aurora Leigh," The Poetical Works of Elizabeth Barrett Browning (London: Smith, Elder \& Co., 1897), as rpt. EPD.

35 "Gods," Passage, LG (1872), sep. pag. 115. It is interesting that Chase omits the second stanza, "Lover Divine, and Perfect Comrade! / Waiting, content, invisible yet, but certain, / Be thou my God."

38 John 18:37.

39 It is not known which parody Ella sent to George. Whitman was more often parodied in the 1880 s and 1890 s than he was in the 1860 s and 1870 s. Perhaps she sent "From W-T W-TM-N," published on February 29, 1868, in Every Saturday or "I am Walt Whitman," published on December 12, 1868, in London's Once a Week. Chase's mild approval suggests the former rather than the latter. See Henry S. Saunders, Parodies on Walt Whitman (New York: American Library Service, 1923), 21-22.

40 Goldwin Smith (1823-1910) was an English historian, prolific social critic, and author of a popular study of William Cowper.

41 Chase quotes the final stanza of N.P. Willis's "Love in a Cottage." The lines are inaccurate in several ways. Willis wrote, for example, that true love was at home "on a carpet," and not "in a parlor." Likewise the arrows of true love are tipped with "a jewel" in the original. As with the numerous other inaccuracies, these differences suggest Chase habitually quoted from memory. See Willis, Poems of Nathaniel Parker Willis, with a Memoir of the Author, by H.L. Williams (New York: Hurst \& Company, 1882), as rpt. $A P D$.

42 Longfellow's famous translation of Seneca's complaint ("Vita brevis est, ars longa") from his "A Psalm of Life" (1838).

43 George Macdonald (1824-1905) wrote many poems and novels that were popular for their mysticism and their description of humble life in Scotland. 
44 This Sunday Magazine was published in Philadelphia by J. B. Lippincott.

45 An expression made famous by Ariel's "Full fathom five" song in The Tempest, I:ii.

46 "Minnesota" is a Sioux phrase meaning "the land of the sky-tinted waters."

47 Chase alludes to "The Upright Man" by English poet Henry Ellison [Browne] (1811-1890). According to Ellison, the upright man "wears his heart upon his sleeve, / Though spiteful daws may peck at will, / And, though his fellow-men aggrieve, / His heart of good they cannot kill." See Ellison, The Poetry of Real Life: A New Edition, Much Enlarged and Improved (London: G. Willis, 1851), as rpt. EPD.

48 See note 23.

49 Chase quotes Robert Burns's “Address to the Unco Guid, or the Rigidly Righteous," a 1786 poem that begins with a brogue paraphrase of Solomon's advice in Ecclesiastes 7:16: “My Son, these maxims make a rule, / An' lump them ay thegither; / The Rigid Righteous is a fool, / The Rigid Wise anither." Robert Burns, The Poetry of Robert Burns, ed. William Ernest Henley and Thomas F. Henderson (Edinburgh: T.C. and E.C. Jack, 1896), as rpt. EPD.

50 Chase must be using an abbreviated title for this unknown book of poems.

51 Hamlet, IV:v. According to Ophelia, rosemary is for remembrance, pansies are for thoughts.

52 Henry Flagg French (1813-1885), a Cambridge lawyer and District Attorney, served as the Assistant Secretary of the U.S. Treasury from 1876 to 1885 . The 1872 Boston Directory notes that French's home was in Concord.

53 Phineas Parkhurst Wells (d. 1891) was the author of homeopathic treatises on diarrhea, dysentery, and intermittent fever.

54 Florence Lee identifies Will F. as William Folwell. Folwell (1833-1929) was the valedictorian of New York's Hobart College (1857), the first President of the University of Minnesota (1869-1883), and the author of a four-volume history of Minnesota revised as recently as 1956. Folwell appears in Whitman's daybooks in October 1877 ("Pres'dt University of Minnesota. / William W. Folwell / Minneapolis, Minnesota"); $D B N, 1: 64$.

55 If Wheeler wrote such a letter it is lost. Edwin Haviland Miller's revised calendar of letters written to Whitman describes no correspondence from Folwell or Wheeler. See Miller, "A Revised Calendar of Letters Written to Whitman," The Correspondence of Walt Whitman: A Second Supplement (Iowa City: Walt Whitman Quarterly Review Press, 1991), 43-96. 